\title{
Association Between a Functional Polymorphism in the MAOA Gene and Both Emotional Coping Style and Neuroticism
}

Sandra Lopez-Leon ( $\nabla$ sandra.lopez@novartis.com )

https://orcid.org/0000-0001-7504-3441

Diego A. Forero

Universidad Antonio Narino Facultad de Medicina

Ana Adan

Universitat de Barcelona

Research note

Keywords: MAOA gene, Mental health, Emotion-oriented coping, Neuroticism

Posted Date: November 2nd, 2019

DOl: https://doi.org/10.21203/rs.2.13770/v2

License: (c) (i) This work is licensed under a Creative Commons Attribution 4.0 International License.

Read Full License 
The authors have withdrawn this preprint from Research Square 